PRZEGLĄD WSCHODNIOEUROPEJSKI X/1 2019: 37-46

NAUM Gregory Katz

ORCID https://orcid.org/0000-0002-5856-5368

Carnegie Mellon University

\title{
DREAM AND REALITY IN THE LIFE OF NICHOLAS LOCHOFF: ON THE HISTORY OF THE CREATION OF NICHOLAS LOCHOFF'S PITTSBURGH CLOISTER
}

KeYwords: cloister, Nicholas Lochoff, Ivan Tsvetaev, Helen Clay Frick, Bernard Berenson

Aвstract: This article recounts the unusual fate of the artist-copyist Nicholas Lochoff. Lochoff, who lived most of his life abroad, in Italy, remains relatively unknown in his Russian homeland. Based on Russian and American historiography, and the periodical press, the author follows Lochoff's path from professional revolutionary to self-taught artist who became recognized as one of the leading copyists of the twentieth century. As research shows, the philanthropy of Helen Clay Frick enabled the University of Pittsburgh to acquire Lochoff's unclaimed copies of European masterpieces where they became an asset in educating future generations of American art historians.

Can an amateur artist without any professional or academic training whatsoever become a leading artistic copyist whose works grace the walls of the best museums and private collections in Europe and the America? Most people would reflexively shake their heads no in response to this essentially rhetorical question. Still, the history of world art contains sufficient examples of individuals who, without any formal schooling, successfully developed their talents and garnered the highest praise from their contemporaries. The Russian émigré artist, Nicholas Lochoff, who spent a large portion of his life in Florence, Italy where he died and was laid to rest, can be numbered among these.

The author of the present article "discovered" Lochoff for himself about thirty years ago during a visit to the building on the University of Pittsburgh campus that houses the Department of Art History and Architecture. In the building's small internal courtyard that recalls the courtyards of Pompeii down to the traditional fountain in the center, beneath the roof that runs above the perimeter of its arcade, one finds a collection of copies of famous paintings from the Italian Renaissance. A small explanatory note on the wall introduces the copyist - Nikolay (Nicholas as he was known in Italy) Lochoff - and describes the almost fantastic history of how his reproductions of original works of art located in the Uffizi Gallery, 
and the churches and monasteries of Italy came to be in Pittsburgh, and how this collection came to serve as the centerpiece of a building erected especially for him.

Until recently, the name of Lochoff the artist, like the names of many of his contemporaries who left Russia early in the twentieth century, had been forgotten in the land of his birth. So forgotten, in fact, that the efforts of family and friends to see his masterful works transported to his homeland met with consistent failure. Only in the early 1990s, thanks to the labors of Russian regional art specialists and historians and art historians, did the name Nicholas Lochoff again appear in print. Fascinating publications about his creative output appeared on the Internet. Then, in 2017, a wonderful monograph prepared by T. Veresova and M. Talalay, appeared containing a wealth of previously unpublished documentary and archival material from Russia and abroad on his life and the fate of his creations. The authors even succeeded in engaging Lochoff's grandson, the Italian art scholar, Niccolo Cruciani, to supply documents and photographs from the family album, and to graciously write an introduction for the volume entitled, "My Grandfather" (Veresova 2017).

These new Russian publications, together with the research of American art historians, have a bearing, directly and indirectly, on the cultural history of the city of Pittsburgh, particularly in regard to the collecting activity of Helen Clay Frick. They have made it possible to recover previously unknown facts from the artist's life in Russia and his sojourn in Italy.

Among the recently uncovered information is an entry under the year 1872 in the registry book from a church in Pskov recording the birth and baptism of a son named Nicholay to the merchant Lochoff. For centuries, Pskov and its inhabitants defended the north-western borders of the country, and ancient, provincial Pskov remains a city distinguished by its special beauty. The Pskov Kremlin and its numerous cathedrals and churches, with their frescoes and icons, dominate the landscape. A center of medieval icon production, many talented representatives of the Russian intelligentsia came from this remote city; surely the city and its history helped nurture Lochoff's creative energies. Pskov's remoteness and forbidding climate also made it a common place of exile for many political opponents of the tsarist regime. It is quite possible that as a schoolboy the impressionable adolescent came to know some of them, and that these encounters had a bearing on his later revolutionary activities.

Ten-year old Nicholas Lochoff studied at the Pskov Men's Gymnasium, and then transferred to the Saint Petersburg Gymnasium of the Imperial Philanthropic Society, which he completed in two years. In 1893, Nicholas was accepted as a student in the Physics and Mathematics Department of the Saint Petersburg Imperial University where he studied natural sciences. The professors whose lectures he attended included some of the leading lights of Russian science in the secondhalf of the nineteenth century such as V. V. Dokuchayev, who offered a course 
on mineralogy, and the botanist, A. N. Beketov. Archival materials, especially Lochoff's personal file, indicate that his time at the university was rather chaotic. He did not always pass his examinations. Illness forced him to leave the university to take an extended cure at a sanatorium in Yevpatoriya in Crimea. From there, he returned to St. Petersburg to resume his studies. When he did return he petitioned university authorities to permit him to attend lectures offered by the law department while continuing his physics and mathematics program of study. Nicholas' growing interest in Russian political developments most likely lay behind this request (TsGA SPb F. 14. Op. 3. D. 30023).

As a student, Lochoff spent much of his free time in the Hermitage copying the paintings of the old masters. The available evidence indicates that he never completed his studies. Instead, he was expelled from the university and sent back to Pskov. His revolutionary activity, especially his participation in student demonstrations and strikes, no doubt brought his university life to conclusion. By this time, he had read the fundamental works of Marxism, and was familiar with the writings of the first Russian Marxist, G. V. Plekhanov. He was also an active member of the "Union for the Liberation of the Working Class" founded by Lenin in 1894-95.

In early 1900, Lenin himself arrived in Pskov after a three-year Siberian exile. Denied permission to live in St. Petersburg, he resumed his political activity here. For his part, Lochoff entered the group of the so-called "Pskov Iskraists" responsible for organizing the publication of the social-democratic newspaper, "Iskra", abroad. By this time, however, Lochoff had already fundamentally diverged from Lenin's political ideas. He now supported the German socialist E. Bernstein, who rejected extreme revolutionary methods in the struggle for political power, declaring instead that the improvement of the economic situation of the working class, and eventually socialism, could be better achieved through peaceful means via legislative reforms. Lenin considered this position a deviation from Marxism, and sharply criticized Lochoff for his heresy.

While in Pskov awaiting an order from the government to travel to Astrakhan, his ultimate place of exile, Lochoff conceived a plan to slip across the border while in transit. In St. Petersburg, Lochoff had met and fallen in love with Maria Sizareva, a student at the Bestuzhev Courses. She was an ardent revolutionary who had been arrested a number of times and even exiled. Nicholas convinced Maria to accompany him on his flight from Russia. After many adventures on the road, including an encounter with smugglers who helped them, Maria and Nicholas crossed the Russian border on Christmas day 1900. Maria remained a faithful and devoted wife and partner to Lochoff, destined to share all his joys, success, and sadness (Veresova 2017, 39-43).

Lochoff continued to develop his interest in painting while abroad, visiting European museums and copying the works of the Renaissance masters until 1905. 
Politics, however, remained central to his life. From 1900 to 1902, while in Geneva, Lochoff participated in the publication of the, "The Worker's Thought", the organ of the so-called "economists," revolutionaries who sought to organize workers on the basis of economic rather than political demands. He also became a member of the "Union of Russian Social-Democrats Abroad".

1903 was an eventful year in the history of Russian social-democracy. Lenin's insistence that the Second Congress of the Russian Social-Democratic Workers' Party adopt his faction's program split the movement. Nicholas had entered the foreign section of the organizational committee of the congress from the "Union of Russian Social Democrats Abroad." His name does not appear among the list of delegates, however. The economists had become sworn enemies of Lenin's Bolshevik faction. In his correspondence, Lenin refers to one "Ol'khin" (Lochoff's political pseudynom) with instructions that he be isolated and detached from the party's foreign committee. Following the congress, Lochoff abandoned his revolutionary activity (Lenin 1967, 612).

At the height of the First Russian Revolution, in October 1905, the Tsar's government granted amnesty to those who had committed political offenses. This enabled Lochoff to return to his homeland. After a short stay in Pskov where he met with family and friends, he moved on to St. Petersburg to put his natural talent as a copyist and restorer to use.

Lochoff carried with him examples of the copies he had completed abroad. N. Rerikh, the famous Russian artist and Secretary of the Imperial Society for the Encouragement of the Arts, not only exhibited one of his paintings at the Society, but purchased it for the Society's museum. Rerikh's patronage helped Lochoff sell many of his works to collectors, including copies made in the Hermitage, Louvre, and other museums. Between 1906 and 1907, Lochoff occupied himself by duplicating the Renaissance masterpieces in the Hermitage collection. These works further cemented his reputation as a talented copyist. Then, in 1907, Lochoff traveled to Florence. This probably occurred under the auspices of the Society to Encourage the Arts, or the Academy of Artists, or perhaps even the Hermitage itself.

In 1910, Lochoff began his collaboration with I. Tsvetaev, the founder and first director of the Alexander III Museum of Fine Art (now the Pushkin State Museum of Decorative Arts) in Moscow. A significant figure in the history of Russian culture, Tsvetaev firmly believed in the enormous educational role of art for society and in the life of each individual. He dreamed of creating a museum that would allow all those who lacked the means to travel to the great museums of the world to see the achievements of world art with their own eyes. In Tsvetaev's opinion, a museum that presented true and accurate reproductions of architectural, sculptural, and painting masterpieces would help instill a love of art in the population at large. Tsvetaev's aesthetic vision corresponded precisely to Lochoff's own creed and mission in life. 
The artist dreamed of saving the world through the beautiful and excellent, in other words through art. While noble, this utopian outlook, as history has demonstrated, was simplistic and naïve.

To realize Tsvetaev's vision, a "Society of the Friends of the Idea of Lochoff" was created, and a sponsor, V. Yakunchikov, the industrialist and patron of the arts, found. Yakunchikov agreed to finance the artist's work abroad. The parties specified that the next step would include copying the work of Sandro Botticelli, Giovanni Bellini, Beato Angelico, and other Renaissance masters held in museums, monasteries, and churches in Florence, Milan, and Pisa. Tsvetaev, in his correspondence with the artist, recommended that masterworks of other Italian artists of the fourteenth to the sixteenth centuries also be added together with portraits of great painters, and famous figures from Italian history.

History, however, intervened and cruelly ended Lochoff's mission for the Moscow museum. Tsvetaev died in August 1913, and within a year the First World War began. In 1916, Yakunchikov, also died. Lochoff received a telegram from his late sponsor's widow in September 1917 informing him that wartime conditions made it impossible to continue to send money. Despite these losses and his separation from Russia, Lochoff remained in Italy and continued to work.

According to Mary Logan Berenson, before 1917 Lochoff had managed to send eight paintings to Tsvetaev's museum, and had promised to make and dispatch nearly fifty more. (Berenson 1930, 628) However, in October 1917, at the time of the Bolshevik revolution, nine unsolicited copies remained in Florence ready for shipping.

The artist desperately needed money to continue his work. Yet all attempts to borrow against his paintings proved fruitless. Compounding the problem, after the October Revolution, the Italian government sharply changed its policy toward the Russian émigrés who could no longer hope to receive any assistance from that quarter. For many years, Lochoff continued to live on the hope of sending his works to Moscow and refused to sell the copies that Tsvetaev had ordered even if this meant starvation (Berenson 1930, 632).

To make ends meet, Lochoff, incredibly, undertook to make two copies of each painting simultaneously - one for the museum, and one for the marketplace. By the early 1920s, the fame of the extraordinary Russian copyist had spread throughout Italy and had spilled over its borders into the wider world. Many museums and churches, as well as private collectors in Europe America, and Australia, began to purchase his work. The Italian government, fearing for the future of the frescoes and paintings located in famous churches and palaces of Florence, Assisi, Venice, Padua, Rome, and other cities, trusted him alone to copy them. As a highly knowledgeable expert, Lochoff was also invited for consultations in Paris.

Lochoff's popularity among American art collectors brought him to the attention of Bernard Berenson, the American art historian, author of numerous publications, 
and a leading expert on Renaissance painting. Berenson enthusiastically promoted his work among international collectors. The Fogg Art Museum at Harvard University, the Portland Museum of Art, and St. Mark's School in Salisbury all purchased his reproductions of masterworks.

Among private collectors, Helen Clay Frick, one of the wealthiest women in America, and daughter of the businessman, financier, and art patron, Henry Clay Frick, whose art collection and neoclassical Manhattan mansion provided the basis for the museum that carries his name, evinced a special interest in Lochoff's copies.

In 1923, she ordered a copy of Duccio di Buoninsegna's Siena altarpiece, "Maestà." Lochoff could not complete the commission, however, since the painting had suffered badly under a previous restoration, making it impossible for him to discern its original appearance (Sanger 2007, 166). Miss Frick then intended to order a copy of another "Maestà" by Simono Martini in the Palazzo Pubblico in Siena. Frick's recently published correspondence with Edward Forbes, director of the Fogg Museum, indicates that for this work, which would require four years labor, Lochoff requested a payment of $\$ 100,000$. Frick considered this sum exorbitant. In her opinion, a copy, however masterful, remained a copy. Forbes suggested contacting Mussolini in order to secure financial assistance for the artist even if just to pay the expenses of his studio. Frick did not follow his advice, however, and ultimately decided not to pursue the commission (Veresova 2017, 214-218).

In 1928, she did commission Lochoff to copy Pietro della Francesca's frescoe, "Resurrection," in the Palazzo della Residenza in Sansepolcro, for the University of Pittsburgh's Department of Fine Arts. She also ordered a copy of Pietro Lorenzetti's frescoe, "Madonna with St. Francis and St. John the Evangelist," in the Papal Basilica of St. Francis of Assisi in Umbria, which she intended for the reading room of the Frick Art Reference Library in New York. In one letter, Frick discusses the deep impression a visit to Lochoff's studio made on her when she and her mother viewed his studies for the della Francesca fresco on 30 September 1928 (Sanger 2007, 166).

When news of Frick's Lochoff commission reached John Bowman, Rector of the University of Pittsburgh, he resolved to put his plan for a new building into action. Bowman invited Charles Z. Klauder, a famous architect who specialized in designing university campuses, to draft plans for a building to house a Department of Fine Arts. Aware of Frick's anti-German biases, Bowman nonetheless placed his trust in Klauder's ability hopeful that the latter's German ancestry would not obstruct the project. On learning that Klauder was a native-born American from Philadelphia, Frick did not oppose Bowman's decision (Sanger 2007, 166).

Lochoff's commitment to the integrity of the original led him to always manufacture his own paints (aided, no doubt, by knowledge of chemistry acquired during his university days). This effort to recapture the techniques and secrets of the old masters also helped him to imagine himself as a participant in the events depicted in the original paintings (Veresova 2017, 67-68; Hovey 1967, 3). During 
his work in Florence, Lochoff had succeeded in discovering a type of tempera very similar in composition to that used by the Renaissance masters. He kept this find a closely guarded secret, and gave evasive answers to the queries of his colleagues on the matter, recommending only that they study the published literature. Many Italian restorers also remarked that on canvases restored by the Russian, one could not tell where the old master's brushwork ended and that of the restorer began (Veresova 2017; 70, 236-238).

Lochoff was determined to produce copies as close as possible to the originals. In pursuit of this goal, he purposely "aged" them by applying a "patina of time," appropriate to the original. Thus, the artist worked for eighteen months in the galleries of the Uffizi copying Botticelli's "Birth of Venus," and his version did indeed appear as Botticelli's masterpiece must have at the time of its creation. Yet, he required a further six months "to bring" the copy to its "original" condition (Berenson 1930, 631). Berenson, himself, convinced Lochoff to maintain the original's primordial freshness. In 1930, Mary Logan Berenson recalled the shock she experienced during a visit to the artist's studio. In her opinion, such scrupulous recreation of so many brilliant masterpieces was a sort of miracle that had never been seen before in the history of European art (ibidem, 628).

A genuine patriot, Lochoff never forgot his promise to Tsvetaev. Even as he carried out commissions for collectors and museums, he continued to make copies for the museum in Moscow. Thus, by the mid-1930s, he had finished approximately forty copies that remained unclaimed. Unfortunately, at this time, the Soviet Union had no use for his work. To raise funds for industrialization, the leadership had already begun to sell gold abroad, seizing valuables from churches and individuals, and even requisitioning the treasures held in museums. Between 1928 and 1933, the Soviet government placed canvases from the Hermitage collection on the market. As a result, 24,000 works of art, including works by Raphael, Rembrandt, and Titian, were auctioned off, departing Russia forever. Andrew Mellon, the American banker, industrialist, and art collector, alone acquired twenty-one masterpieces for a total of $\$ 6,600,000$ (Semenova 2013, 128-223). Given this situation, there could not even be any talk of buying copies from an émigré artist.

Despite these setbacks, the friendship of other émigré artists served as a bright spot in the life of the Lochoff family. Nicholas especially enjoyed his relationship with Latvian artist, Evgenij Klimov, an expert on northern and Pskov church architecture and painting who had relocated to Canada following the Second World War. Born in Moscow to parents who had emigrated from Great Britain, Eric Pren was another family friend. Pren had studied painting in Riga, but in 1939 he left the country with his family for England.

In the second-half of the 1930s, as a result of the economic crisis and resulting depression, collectors' interest in Lochoff's copies significantly declined. In addition, Mussolini's aggressive foreign policy - his bloc with Nazi Germany and Italy's 
entry into the Second World War - undermined the normal development of art in Lochoff's adopted country. The Duce's cardinal principle regarding art became "a return to order." The famous Italian futurist and fascist supporter, Carlo Carra, characterizing the relationship between the fascist idea of law and order and the tasks of creative art, wrote that for the regime modern art must, in its spirit, fundamentally distinguish itself from the art created by the old masters (Flint 1980, 49-54). This idea was fundamentally at odds with Lochoff's conception of the artist's mission.

It should be noted that Lochoff's life from the end of the 1930s through the years of the Second World War has yet to receive sufficient scholarly attention. Obviously, financing for restorations of the works of old masters practically ceased. Artists now found themselves in dire conditions. With the end of the war and the destruction it had visited on Italy, the situation became even worse. Maria Lochoff's correspondence with Klimov reveals Nicholas' creative and physical depression. In 1948, forgotten by everyone, deprived of his means of existence, even of his Florence studio where unclaimed copies of frescoes and painted canvases which might have hung in the best Moscow and Leningrad museums were stored, Nicholas Lochoff died unaware of the future fate of his creative output.

Soon, the artist's widow began to write to Igor Grabar, a well-known Soviet artist and director of the Institute of Art History of the USSR Academy of Sciences. Curiously, during the war Grabar had advanced the idea of compensating Soviet museums for the losses they had incurred during the occupation at the expense of the museums of Germany and her allies (Akinsha 1995, 20). Grabar, however, citing a variety of circumstances, refused, or perhaps simply was afraid, to purchase the works of a Russian artist who had lived abroad, in order to return them to the country for which they had always been intended.

The Lochoff family financial situation had become critical. Lacking a breadwinner, it became necessary to sell the collection. They hoped to keep the collection intact and not sell it off piecemeal. Aware of the situation, the ninetythree-year old Berenson came to the rescue. He proposed to Helen Clay Frick that she buy the entire collection.

In 1958, she traveled to Florence to buy the Lochoff collection. Boris, the artist's son, led her to his father's studio and showed her twenty-three canvases. She wrote to Berenson on 3 July 1958 to inform him of her difficult decision to purchase the collection. Initially, Lochoff's heir quoted a price of $\$ 60,000$, but in the course of negotiations this figure was reduced to $\$ 40,000$. The family of the late artist agreed to this sum, abandoning hope that the collection would fetch more. The deal was finalized on 30 July when Frick's lawyer and banker approved the appropriate documents (Sanger 2007, 275).

The University of Pittsburgh, for its part, had yet to erect the promised building for the Department of Fine Arts. Miss Frick originally intended to keep the Lochoff collection in Clayton, the family's Pittsburgh mansion (Kirkland 2003). She even 
considered constructing a building there to house the collection along the lines of the famous Cappella degli Scrovegni in Padua known as the Arena Chapel (Sanger 2007, 275). Later, however, she decided to donate the collection to the Department of Fine Arts founded by her in 1925 and named in honor of her father. Frick well understood that the Russian master's oeuvre would create a special pedagogical aura that would serve to interest the young in art. In 1925, she had already donated $\$ 75,000$ for the needs of the department, and soon after, through her efforts, it became one of the leading departments in the country (Alberts 1986, 107).

In a letter to University Chancellor, Edward Litchfield, dated 12 October 1958, the department chairman, Professor Walter Hovey, wrote that Miss Frick was categorically opposed to any modernist architecture for the new building and was also opposed to locating the department in a wing of the university library (Sanger 2007, 275). Known not only for her wealth, but also for her eccentricities, she constantly changed her demands regarding the architectural style of the projected building and its location. She insisted, however, that the building immortalize her father's name.

In 1959, Lochoff's copies arrived at the University of Pittsburgh. An exhibit that displayed only twelve paintings from the collection opened on 4 November and attracted throngs of people becoming a significant event in the city's history. After lengthy discussions about its permanent location, a compromise was reached. On Frick's suggestion it was decided to construct a building in the Italian Renaissance style around the cloister that housed Lochoff's copies. (Fifield 1996, 85). The architectural firm of B. Kenneth Johnson designed a two-story building of grey limestone with a bas-relief of Henry Clay Frick by the sculptor Malvina Hoffman situated above the main entrance. The cloister itself was designed in the style of the arcade of the famous Florentine church, Santa Maria Novella (Sanger 2001, 31). Construction began in 1962 and the building opened in 1965.

In addition to the cloister, lecture hall, university art gallery, and other teaching auditoriums, the building has a well-appointed library paneled in wood, custom-made tables, and, of course, book shelves with art books and catalogues that Helen Clay Frick began to purchase for the department in 1927 and that eventually numbered more than 100,000 volumes (Kirkland 2003). The Henry Clay Frick Fine Arts Building became the third building in Pittsburgh containing artistic treasures and connected to the Frick family along with the family mansion, Clayton, and the Frick Museum of Art (Toker 1986, 101).

Many researchers believe that guilt primarily motivated Helen Clay Frick's philanthropy. They see in it an effort to somehow expunge the crimes committed by her father who, in 1892, mercilessly suppressed a strike of steelworkers at the Homestead plant owned by Andrew Carnegie. While such a motive is credible from a psychological standpoint, all the same, it remains controversial. We must not forget that Carnegie, the founder of the city's steel industry, and Frick, his general 
manager, were some of the wealthiest people in America. At the same time, they took philanthropy seriously, opening museums, libraries, concert halls not only in Pittsburgh, the center of the steel industry, but in other US cities and overseas as well. From this standpoint, Helen Clay Frick's philanthropy deserves only the deepest respect.

Finally, it should be noted, that the cloister became not only the repository of the work of an extremely talented Russian master. It continues to inspire and educate new generations of American art historians. (Pitz 2003) One is fully justified in saying, therefore, that the cloister rightfully keeps alive the ideals of the master who dreamed that his artistic creations would one day transform the world.

\section{Bibliography}

TsGA SPb F. 14. Op. 3. D. 30023, Tsentral'nyy Gosudarstvennyy Istoričeskij Arkhiv Sankt-Peterburga. Fond 14 (Imperatorskiy Petrogradskiy universitet. 1819-1918 gg.). Opis' 3. Delo 30023 (Lokhov Nikolay Nikolayevich. Lichnoye delo studenta). [Центральный государственный исторический архив Санкт-Петербурга. Фонд 14 (Императорский Петроградский университет. 1819-1918 гг.). Опись 3. Дело 30023 (Лохов Николай Николаевич. Личное дело студента).]

Akinsha, K./Kozlov, G. (1995), Beautiful Loot: The Soviet plunger of European's art treasures. New York.

Berenson, M. L. (1930), A reconstruction of old masterpiecies. In: The American Magazin of Art. $\mathrm{XXI} / 11,628-638$.

FifIELD, B. (1996), Seeing Pittsburgh. Pittsburgh.

FLINT, K. (1980), Art and the fascist regime in Italy. In: Oxford Art Journal. III/2, 49-54.

Hovey, W. R. (1967), Nicholas Lochoff cloister of the Henry Clay Frick fine arts building. Pittsburgh. KirkLAND, K. (2003), Schenley fountain, Frick fine arts building honors wealthy namesakes. In: Pittsburgh Post-Gazette. July 20.

Lenin, V. I. (1975), Polnoye Sobraniye Sochineniy. Moskva. XXXXVI/612. [Ленин, В. И. (1975), Полное собрание сочинений. Москва. XXXXVI/612.]

Pitz, M. (2003), Rare Murals Being Restored in Pitt Fine Arts Building. In: Pittsburgh Post-Gazette. May 25.

SANGER, M. F. S. (2007), Hellen Glay Frick: bittersweet heiress. Pittsburgh.

SANGER, M. F. S. (2011), Henry Clay Frick houses: architecture, interiors, and landscapes in the golden era. New York.

Semenova, N./ILJine N. (ed.) (2013), Selling Russia's treasures: The Soviet trade in nationalized art, 1917-1938. New York/London.

Veresova, T. V./Ralalay, M. G (2017), Chelovek Renessansa: khudozhnik Nikolay Lokhov. Moskva. [Вересова, Т. В./Талалай, М. Г. (2017), Человек Ренессанса: художник Николай Лохов. Москва.] 